\title{
Occurrences, levels and risk assessment studies of emerging pollutants (pharmaceuticals, perfluoroalkyl and endocrine disrupting compounds) in fish samples from Kalk Bay harbour, South Africa
}

\author{
Cecilia Y. Ojemaye*, Leslie Petrik \\ Environmental and Nano Science Research Group, Department of Chemistry, University of the Western Cape, Cape Town, South Africa
}

\section{A R T I C L E I N F O}

\section{Article history:}

Received 6 January 2019

Received in revised form

7 May 2019

Accepted 17 May 2019

Available online 24 May 2019

\section{Keywords:}

Pharmaceuticals

Perfluorinated compounds

Fish

Pollutants

Risk assessment

\begin{abstract}
A B S T R A C T
A comprehensive analysis of 15 target chemical compounds (pharmaceuticals and personal care product, perfluoroalkyl compounds and industrial chemicals) were carried out to determine their concentrations in selected commercially exploited, wild caught small and medium sized pelagic fish species and their organs (Thyrsites atun (snoek), Sarda orientalis (bonito), Pachymetopon blochii (panga) and Pterogymmus laniarius (hottentot)) obtained from Kalk Bay harbour, Cape Town. Solid phase extraction (SPE) method based on Oasis HLB cartridges were used to concentrate and clean-up the samples. Liquid chromatography-mass spectrometry analysis of these chemical compounds revealed the simultaneous presence of at least 12 compounds in different parts of the selected fish species in nanogram-per-gram dry weight $(\mathrm{ng} / \mathrm{g} \mathrm{dw})$ concentrations. The results revealed that perfluorodecanoic acid, perfluorononanoic acid and perfluoroheptanoic acid were the most predominant among the perfluorinated compounds and ranged between: (20.13-179.2 ng/g), $(21.22-114.0 \mathrm{ng} / \mathrm{g})$ and $(40.06-138.3 \mathrm{ng} / \mathrm{g})$. Also, diclofenac had the highest concentration in these edible fish species out of all the pharmaceuticals detected (range: $551.8-1812 \mathrm{ng} / \mathrm{g}$ ). The risk assessment values were above 0.5 and 1.0 for acute and chronic risk respectively which shows that these chemicals have a high health risk to the pelagic fish, aquatic organisms and to humans who consume them. Therefore, there is an urgent need for a precautionary approach and the adequate regulation of the use and disposal of synthetic chemicals that persist in aquatic/marine environment in this province and other parts of South Africa, to prevent impacts on the sustainability of our marine environment, livelihood and lives.
\end{abstract}

() 2019 Elsevier Ltd. All rights reserved.

\section{Introduction}

Emerging pollutants such as endocrine disrupting chemicals (EDCs), pesticides, flame retardant, perfluoroalkyl compounds (PFAs) and pharmaceuticals and personal care products (PPCPs) are of environmental and public concern (Daughton and Ternes, 1999; Jin and Peldszus, 2012). They enter the aquatic environment continuously through sewage effluents, wastewater discharge, agricultural runoff, and municipal landfill leachates and these have raised concerns for regulatory agencies worldwide (Gaw et al., 2014). As a result of the continuous discharge of these compounds into the environment, aquatic organisms like fish, which are sensitive indicators for substances that enter aquatic/marine

\footnotetext{
* Corresponding author.

E-mail address: 3714926@myuwc.ac.za (C.Y. Ojemaye).
}

ecosystems can bioconcentrate and also accumulate significant amounts of these compounds several times higher than the surrounding water via diffusion across the gills and skin, regardless of these compounds soluble properties in water (Mottaleb et al., 2009; Togunde et al., 2012; Wang and Gardinali, 2012). The levels found are usually in the low concentration but depending on the compound they can reach up to a few hundreds of ng/g. Fish is regarded to be a unique part of a balanced human diet, which has led to increase in consumption of fish in the last few decades globally (Kalachova et al., 2013; Nácher-Mestre et al., 2010).

Fish act as nonpolar media that can adsorb hydrophobic organic chemicals within the water column. Since birds and humans consume fish, this makes fish good biomonitors for xenobiotic pollutants. The ingestion of foods contaminated with persistent lipophilic chemicals can result in the accumulation of these chemicals in humans. The potential for chemical residues to cross the placental barrier (Waliszewski et al., 2000) even if it were in 
trace concentrations, may cause serious damage in the newborns and therefore raises great concern. Medium pelagic fish is the major source of food and thus contamination for both top marine predators and human consumers.

Most of these persistent organic chemicals are found together in the environment in the ng/L range nevertheless, many of these compounds have been linked to environmental effects, including endocrine disruption, histopathological disorders, feminisation/ masculinisation of marine life by hormones, antimicrobial resistance, and other risks to primary production (Bringolf et al., 2010; Cabello, 2006; Jakimska et al., 2013; Johnson et al., 2008; Richardson et al., 2005; Sapkota et al., 2008; Sumpter, 1995). Toxicity tests and risks need to be taken into consideration not only at the species level but also at the consumer level through the possible ingestion of contaminated sea-food, especially fish.

EDCs, in particular, have attracted a lot of attention in the last decade and the number of published studies, describing EDCs levels in marine organisms, is considerably high (Jakimska et al., 2013; Liu et al., 2011; Montesdeoca-Esponda et al., 2018; Yao et al., 2018b, 2018a; Yu and Wu, 2014), perfluorinated compounds (Delinsky et al., 2010; Hölzer et al., 2011; Malinsky et al., 2011; Pan et al., 2011; Shi et al., 2012, 2010a; Stahl et al., 2014; Zabaleta et al., 2014).

However, the number of papers published reporting the occurrence and levels of PPCPs in marine organisms is considerably lower especially in fish (Chen et al., 2018; Du et al., 2016; Grabicova et al., 2017; Hedrick-Hopper et al., 2015; Kim et al., 2017; Liu et al., 2017a, 2017b; Moreno-González et al., 2016; Togunde et al., 2012; Zhao et al., 2015), studies have been performed mostly in bivalves (Álvarez-Ruiz and Picó, 2019; Arpin-Pont et al., 2016; Bueno et al., 2014; Chen et al., 2015; de Solla et al., 2016; Fabbri and Franzellitti, 2016; Gilroy et al., 2017, 2014; Gomez et al., 2012; Lacaze et al., 2015; Li et al., 2012a; McEneff et al., 2014; Núñez et al., 2016; Teixeira et al., 2017; Wille et al., 2011).

Of particular relevance are effluent-dominated waters, in these waters, even compounds with relatively short environmental halflives may be considered pseudo-persistent due to their continuous discharge from a wastewater/sewage treatment plant. As a result, organisms inhabiting these aquatic environments are continually exposed to these contaminants over their entire life cycle (Mottaleb et al., 2009).

In order to address this, the present study constitutes an attempt to accurately measure the concentrations of fifteen compounds in different fish samples. The compounds were mainly chosen according to their high annual consumption, previous studies about their occurrence in marine biota (Álvarez-Muñoz et al., 2015; Klosterhaus et al., 2013; Moreno-González et al., 2016; Petrik et al., 2017; Wang and Gardinali, 2012), their stability and poor elimination during wastewater treatment as well as the concern about their possible effects on human and aquatic organisms (Pampanin et al., 2016). Although the present study was limited to specific target compounds, further investigations shall be carried out to increase the number of measured analytes and to elucidate levels of conjugated or metabolic forms of the active compounds.

\section{Materials and method}

\subsection{Description of site}

The Kalk Bay harbour is one of the last working fishing harbours on the Cape Peninsula, situated in Kalk Bay, around $30 \mathrm{~km}$ $\left(34^{\circ} 07^{\prime} 45.3^{\prime \prime} \mathrm{S} 18^{\circ} 26^{\prime} 57.3^{\prime \prime} \mathrm{E}\right)$ from Cape Town (Fig. 1), was once a fishing village on the coast of False Bay, South Africa and is now a suburb of greater Cape Town. It lies between the ocean and sharply rising mountainous heights that are buttressed by crags of grey
Table Mountain Sandston (Compton, 2004). The community of fishers uses small trawlers and ply for their trade in False Bay and environs, bringing their catches into the harbour daily from whence it is sold.

\subsection{Sample collection and handling}

The fish species were collected from random daily commercial catches sold from Kalk Bay harbour, Cape Town (South Africa). These fish species are wild caught in the vicinity of Cape Point and its environs in late 2017 by small fishing vessels and sold to the public at the daily fish market. They were wrapped in foil before placing in cooler bags on ice for transportation to the laboratory. The samples were washed with millipore water, weighted, dissected, homogenised, packed in polyethylene bags and stored below $-20^{\circ} \mathrm{C}$ for further analysis. Four species of fish namely Thyrsites atun (snoek), Sarda orientalis (bonito), Pachymetopon blochii (panga) and Pterogymnus laniarius (hottentot) were chosen and used in this study according to their high commercial value and human consumption. The composite sample was freeze-dried, ground in a laboratory blended to a fine powder, and kept at $-20^{\circ} \mathrm{C}$ until its analysed. The lipid content of the homogenate of target species was determined gravimetrically. Table 1 provides information about the sample size, weight and length of each fish species. The samples were analysed according to the following protocols.

\subsection{Analytical protocols}

The following equipments were used: $500 \mathrm{mg}, 6 \mathrm{cc}$ Oasis HLB SPE cartridge (Waters, South Africa), centrifuge, vacuum manifold and pump (VAC ELUT SPS 24 Port Agilent Varian,USA), and $0.45 \mu \mathrm{m}$ filter papers (GF/A, Whatman, UK). All extraction wares, and volumetric flasks used were washed with tap water, rinsed well in methanol, and lastly with deionised water prior to drying. The sample bottles were then air-dried.

\subsection{Standards and reagents}

Reagents purchased were HPLC grade and the standards used were of high purity grade ( $>95 \%$ ): perfluorooctanoic acid (PFOA), perfluoroheptanoic acid (PFHpA), perfluorononanoic acid (PFNA), perfluorodecanoic acid (PFDA), perfluoroundecanoic acid (PFUnDA), bisphenol A (BPA) and acetaminophen (ACT), caffeine (CAF), diclofenac (DCF), lamivudine (LA), triclosan (TS), phenytoin (PHE), sulfamethoxazole (SMX), carbamazepine (CAR), 2nitrophenol, sulfamethoxazole- $\mathrm{d}_{4}$ and acetaminophen- $\mathrm{d}_{4}$ from Sigma Aldrich (South Africa). Individual stock standards and isotopically labelled internal standards were prepared in methanol at a concentration of $1000 \mathrm{mg} / \mathrm{L}$. Stock solutions in methanol were stored at $-20^{\circ} \mathrm{C}$. Working standard solutions were prepared by appropriate dilution of the stock solutions in methanol stored at $4{ }^{\circ} \mathrm{C}$ in appropriate storage amber container glassware to prevent light degradation. Working standard solutions were used for preparation of the calibration curves and for spiking samples in the validation study. The cartridges Oasis HLB (6 mL, $200 \mathrm{mg}$ ) were obtained by Waters Corporation (Mildford, MA, USA). HPLC grade methanol, acetonitrile and acetone from Sigma Aldrich (South Africa), ultrapure water was purified by Milli-Q system (Millipore, Bedford, MA, USA).

\subsection{Extraction protocol}

After suitable dissection of different parts of fish samples (fillet, gills, liver and intestine) were freeze-dried and ground whole in a 


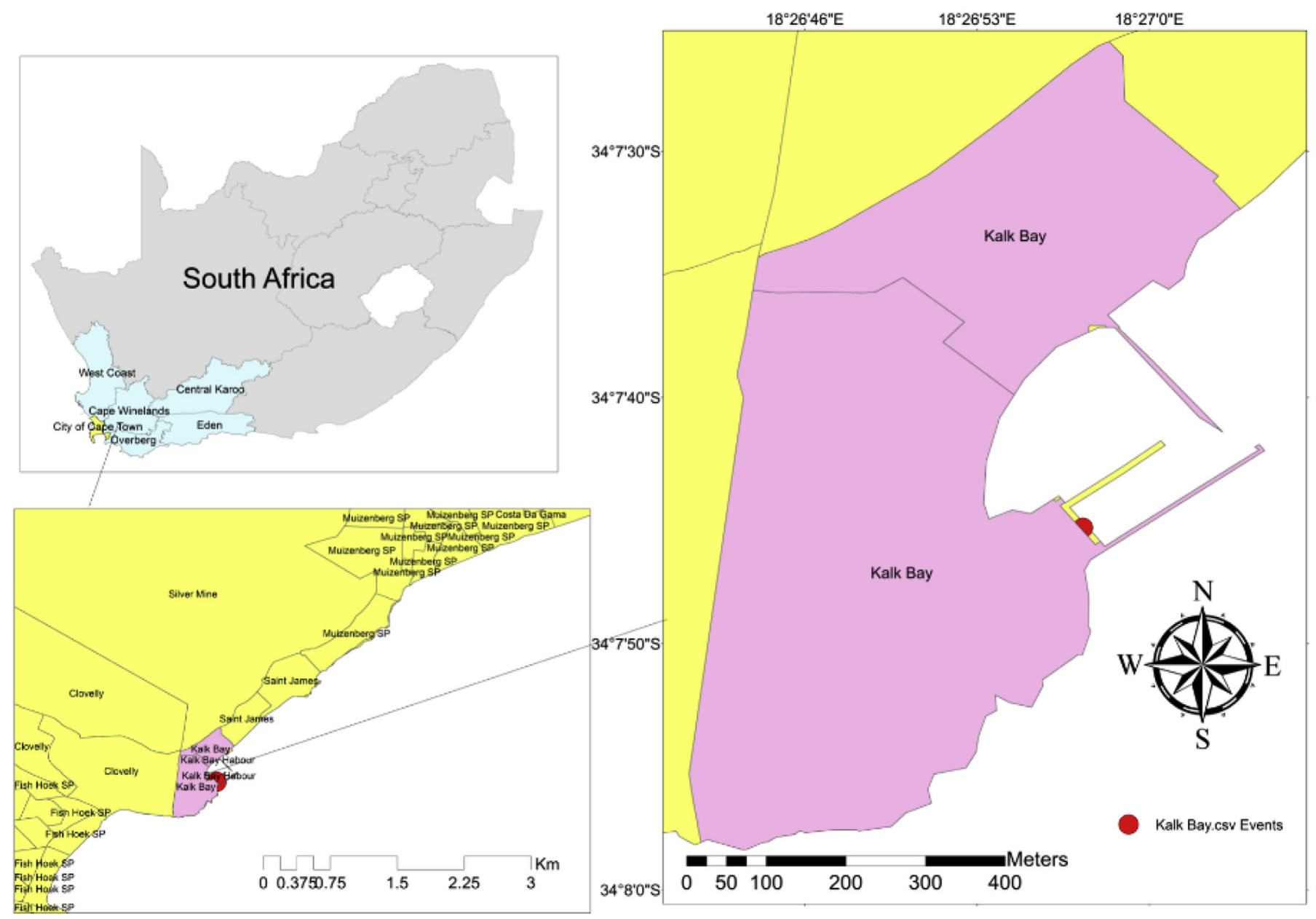

Fig. 1. Map of sampling location for Kalk Bay harbour.

stainless steel industrial blender into a fine powder. Approximately $10 \mathrm{~g}$ of the dried sample was extracted by using a soxhlet extraction method. The extraction solvent used was methanol/acetone 3:1 $(\mathrm{v} / \mathrm{v})$ and the extraction volume was $100 \mathrm{ml}$. The extract was concentrated to $10 \mathrm{~mL}$ using a rotary evaporator at reduced pressure, and the sample $\mathrm{pH}$ was adjusted to 6 by adding $1 \mathrm{M} \mathrm{NaOH}$ to allow the precipitation of lipids. The extract was centrifuged at $3000 \mathrm{~g}$ for $20 \mathrm{~min}$. The supernatant was transferred to polypropylene bottles and millipore water was added to make up to a volume of $100 \mathrm{~mL}$.

\subsection{Cleanup}

Oasis HLB cartridges (6 cc/200 mg; Waters Corp., Franklin, MA) were employed for the fish extract clean-up. The cartridges were conditioned with $7 \mathrm{~mL}$ of methanol followed by $7 \mathrm{~mL}$ of Milli-Q water. Care was taken not to dry the cartridges during the loading process. A cartridge flow rate of less than $1 \mathrm{~mL} / \mathrm{min}$ was operated under the vacuum of $20 \mathrm{psi}$. Once the samples had passed through the cartridges, they were washed with $2 \mathrm{~mL}$ Milli-Q water and air-dried for 20 min under a vacuum. The analyte in the cartridges were eluted with $7 \mathrm{~mL}$ of methanol. Final extracts were evaporated to dryness under a gentle stream of nitrogen, reconstituted in $2 \mathrm{~mL}$ of methanol and $10 \mu \mathrm{L}$ of a $1 \mathrm{ng} / \mu \mathrm{L}$ mixture containing the internal standards were added. Samples were transferred and analysed by LC-MS/MS.

\subsubsection{Analysis by liquid chromatographic mass spectrometry}

The chromatographic separations were carried out with a Waters Acquity Ultra-performance ${ }^{\mathrm{TM}}$ liquid chromatography system (UPLC), equipped with Acquity binary solvent manager and Acquity sample manager. Simultaneous determination of all the compounds of interest was achieved using an Acquity BEH C18 $1.7 \mu \mathrm{m}$ column $(2.1 \mathrm{~mm} \times 1000 \mathrm{~mm})$ with an Acquity BEH C18 $1.7 \mu \mathrm{m}$

Table 1

Weight and length of the fish species.

\begin{tabular}{lll}
\hline Fish species & $\mathrm{n}$ & Weight $(\mathrm{kg}) \mathrm{Mean} \pm \mathrm{SD}$ \\
\hline Snoek (Thyrsites atun) & 8 & $3.85 \pm 0.07$ \\
Bonito (Sarda orientalis) & 6 & $2.33 \pm 0.04$ \\
Panga (Pterogymnus laniarius) & 5 & $0.30 \pm 0.00$ \\
Hottentot (Pachymetopon blochii) & 5 & $0.26 \pm 0.03$ \\
\hline
\end{tabular}

$\mathrm{n}=$ no of each fish sample analysed. 
VanGuard ${ }^{\mathrm{TM}}$ precolumn $(2.1 \mathrm{~mm} \times 5 \mathrm{~mm})$, supplied by Waters (Mildford, MA, USA). The column temperature was set to $50^{\circ} \mathrm{C}$. The mobile phase consisted of a mixture of $0.02 \mathrm{M}$ formic acid (solvent $A$ ) in water, and acetonitrile (solvent B). Linear gradient elution of $0.35 \mathrm{~mL} / \mathrm{min}$ was used by starting with a mixture of solvent $\mathrm{A}(80 \%)$ and solvent B (20\%) for $9 \mathrm{~min}$. At $10 \mathrm{~min}$, the acetonitrile percentage was increased linearly from 80 to $100 \%$ and was later maintained at $80 \%$ of solvent A and $20 \%$ of solvent B. The sample volume injected was $5 \mu \mathrm{L}$ for each sample. Standards and the test samples were subjected to 12 min chromatographic run.

The UPLC was coupled to a triple quadrupole mass spectrometer (Xevo TQ-MS), with an electrospray ionisation (ESI) source. During optimisation, a multiple reaction monitoring (MRM) scan mode was generated for all analytes. In addition, for maximum sensitivity, other conditions such as source temperature, capillary voltage, cone voltage, cone gas flows and desolvation temperatures were standardised. This was achieved by direct injection of stock solutions with a concentration of $10 \mu \mathrm{g} / \mathrm{mL}$. The capillary voltage of $3.5 \mathrm{kV}$, desolvation gas $\left(\mathrm{N}_{2}\right)$ flow of $800 \mathrm{~L} / \mathrm{h}$, source temperature of $140{ }^{\circ} \mathrm{C}$ and desolvation temperature of $400^{\circ} \mathrm{C}$ were finally used. The whole analytical operation control and data processing were performed with Masslynx software.

\subsection{Method validation, quality control and calibration}

A validation study was carried out to show the applicability of the analytical method. The assessment of method linearity, precision, specificity/selectivity, recovery, and calculation of the limits of detection (LODs) and quantification (LOQs) was included for the validation procedure. A triplicate extraction was done to ascertain the concentration and consistency in the extraction technique for all the analytes. The analytical method was validated using EU Commission Decision, 2002/657/EC as a guideline (EU Commission Decision, 2002). Six point calibration curves were constructed (four replicates). An identical validation study was performed using ultrapure water and seawater to demonstrate the multi-matrix capacity of the analytical technique. Blank samples of ultrapure water were extracted and analysed along with the fish samples and laboratory spikes to monitor potential laboratory contamination. Methanol blanks were also run between samples in order to monitor instrumental contamination and carryover. Signal noise, chromatographic peak area and height were used to characterise the analytes of interest; peak area was used to measure the optimal signal intensities for quantification. This provided the most reliable response among the chromatographic response choices such as the peak height and the signal-to-noise ratio. Recoveries of target analyte ranged from 68.8 to $107.5 \%$ (Table 3 ).

\subsection{Risk assessment}

Risk quotient (RQ) is a commonly used ranking criterion to assess ecological risk and is calculated as the ratio of a point estimate of exposure and a point estimate of effects, which is frequently estimated using short-time toxicity data lethal concentration 50\% ( $\left.\mathrm{LC}_{50}\right)$ and No Observed Effect Concentration ( $\left.\mathrm{EC}_{50}\right)$. It is primarily used by US EPA to assess the ecological risk of chemicals.

$$
\begin{aligned}
& R Q=\frac{\text { estimated environmental concentration }(E E C)}{\text { ecotoxicity endpoints }} \\
& R Q=\frac{\text { exposure }}{\text { toxicity }}
\end{aligned}
$$

RQ was calculated according to the EPA guidelines for each compound found in fish in the oceanic ecosystem. The risk presumptions and risk quotient were collected from the website (US EPA, 2016).

\subsection{Statistical analysis}

In this study, all data were analysed using Statistical Package for Social Sciences [(SPSS) IBM version 20 software]. Replicate data were expressed as mean \pm SD and separated by Duncan New Multiple Rang Test. Different samples and sampling sites were compared using one-way analysis of variance (ANOVA). Differences in values were defined as significant when $P$ values were $<0.05$.

\section{Results and discussion}

Table 2 provides the LC-MS retention time, transition and collision energy, limit of detection (LOD), and limit of quantification (LOQ) while (Table 5 supplementary material) provides a summary of analytical concentrations of the pharmaceuticals and personal care products (PPCPs), PFAs and EDC compounds detected in fish fillet, intestines, gills and liver tissues respectively. 7 PPCPs compounds, 5 perfluoroalkyl compounds and 2 industrial chemical compounds were analysed in this study. The target compounds were selected based on the results of our previous study conducted on marine biota (Petrik et al., 2017). According to the study, all the compounds were detected in all the marine biota samples.

Four different part of the fish samples were analysed namely; fillet, liver, gills and intestine. Samples were analysed in triplicate, following the analytical procedure described in Section 2. Nine chemicals compounds were found in Panga fillets, five compounds in Bonito fillets, seven compounds in Hottentot fillet and eight compounds in snoek fillets samples. The fillets of these fish are consumed whereas the gills, intestine and livers are discarded but may form part of fish meal products.

For this study triclosan, lamivudine, bisphenol A and 2nitrophenol were not detected in any of the fish parts.

\subsection{Perfluoroalkyl compounds}

As shown in Table 5, PFUnDA was detected in the fillet of panga fish at a concentration of $124.4 \mathrm{ng} / \mathrm{g}$ while it was not detected in any of the other parts of the fish. PFDA, PFNA, PFHpA and PFOA were detected in all the part of panga fish with the fillet having the highest concentration of $78.86 \mathrm{ng} / \mathrm{g}, 49.53 \mathrm{ng} / \mathrm{g}, 83.86 \mathrm{ng} / \mathrm{g}$ and $37.52 \mathrm{ng} / \mathrm{g}$ respectively, while the intestine, liver and gills range from 27.26 to $57.26 \mathrm{ng} / \mathrm{g}, 21.76-41.76 \mathrm{ng} / \mathrm{g}, 65.56-75.64 \mathrm{ng} / \mathrm{g}$ and $10.91-13.91 \mathrm{ng} / \mathrm{g}$ respectively. The overall distribution of PFCs in panga fish followed the order fillet $>$ intestine $>$ liver $>$ gills.

In bonito fish, PFDA and PFNA were found in all the fish parts with gills having the highest concentration of $84.24 \mathrm{ng} / \mathrm{g}$ and $76.72 \mathrm{ng} / \mathrm{g}$ respectively while the concentration in other parts of the fish ranged from 19.52 to $58.41 \mathrm{ng} / \mathrm{g}$ and $22.89-58.52 \mathrm{ng} / \mathrm{g}$ respectively. PFHpA was detected in all the parts with the fillet having the highest concentration of $297.5 \mathrm{ng} / \mathrm{g}$ while other parts ranged from 95.95 to $110.0 \mathrm{ng} / \mathrm{g}$. PFOA was detected in just the intestine and gills with a concentration of $34.65 \mathrm{ng} / \mathrm{g}$ and $19.91 \mathrm{ng} / \mathrm{g}$ respectively. PFUnDA was not detected in any of the fish parts. Furthermore, out of the perfluorinated compounds, PFHpA had the highest concentration in all the parts of the fish. The overall distribution of PFCs in bonito fish varied from part to part.

In hottentot fish, PFDA, PFNA, PFOA and PFHpA were detected in all the parts with the intestine having the highest concentration of $179.2 \mathrm{ng} / \mathrm{g}, 82.49 \mathrm{ng} / \mathrm{g}, 63.17 \mathrm{ng} / \mathrm{g}$ and $139.1 \mathrm{ng} / \mathrm{g}$ respectively while the concentration in other parts ranged from 32.44 to $159.2 \mathrm{ng} / \mathrm{g}$, $15.92-81.49 \mathrm{ng} / \mathrm{g}, 3.900-61.27 \mathrm{ng} / \mathrm{g}$ and $74.67-130.0 \mathrm{ng} / \mathrm{g}$. However, Quinete et al. (2009) evaluated PFOA in the muscles of mullet 
Table 2

Chemical structures and instrumental parameters for target compounds using LC-MS (Quantitation ions in bold).

\begin{tabular}{|c|c|c|c|c|c|c|c|c|}
\hline Compounds & Family & Molecular structure & $\begin{array}{l}\text { Polarity } \\
\text { (ESI) }\end{array}$ & $\begin{array}{l}\text { Retention time } \\
(\min )\end{array}$ & $\begin{array}{l}\mathrm{m} / \mathrm{z} \\
\text { ions }\end{array}$ & $\begin{array}{l}\text { Collision energy } \\
(\mathrm{eV})\end{array}$ & $\begin{array}{l}\text { LOD (ng/ } \\
\text { g) }\end{array}$ & $\begin{array}{l}\text { LOQ (ng/ } \\
\text { g) }\end{array}$ \\
\hline Acetaminophen & $\begin{array}{l}\text { Analgesics/anti } \\
\text { inflammatory }\end{array}$ & & + & 2.01 & $\begin{array}{l}\mathbf{1 5 2} \\
110\end{array}$ & 15 & 0.023 & 0.077 \\
\hline Sulfamethoxazole & Antibiotic & & + & 3.23 & $\begin{array}{l}\mathbf{2 5 4} \\
156\end{array}$ & 25 & 0.019 & 0.058 \\
\hline Lamivudine & Antiretroviral & & + & 6.43 & $\begin{array}{l}237 \\
194\end{array}$ & 15 & 0.025 & 0.090 \\
\hline Carbamazepine & Psychiatric-antiepileptic & & + & 1.74 & $\begin{array}{l}230 \\
112\end{array}$ & 20 & 0.010 & 0.025 \\
\hline Phenytoin & Anti-epileptic & & + & 6.18 & $\begin{array}{l}253 \\
182\end{array}$ & 15 & 0.034 & 0.098 \\
\hline Diclofenac & $\begin{array}{l}\text { Analgesics/anti } \\
\text { inflammatory }\end{array}$ & & + & $6 . .72$ & $\begin{array}{l}\mathbf{2 9 4} \\
250\end{array}$ & 15 & 0.025 & 0.089 \\
\hline Caffeine & Psychomotor Stimulant & & + & 3.41 & $\begin{array}{l}\mathbf{1 9 5} \\
138\end{array}$ & 20 & 0.027 & 0.083 \\
\hline Triclosan & Disinfectants & & - & 9.09 & $\begin{array}{l}\mathbf{2 8 7} \\
36.8\end{array}$ & 10 & 0.023 & 0.075 \\
\hline Bisphenol A & Industrial chemical & & - & 5.87 & $\begin{array}{l}\mathbf{2 2 7} \\
212\end{array}$ & 28 & 0.014 & 0.047 \\
\hline 2-nitrophenol & Industrial chemical & & + & - & $\begin{array}{l}\mathbf{1 3 9} \\
121\end{array}$ & 15 & - & - \\
\hline $\begin{array}{l}\text { Perfluoroundecanoic } \\
\text { acid }\end{array}$ & Industrial chemical & & - & 8.57 & $\begin{array}{l}\mathbf{5 6 3} \\
563\end{array}$ & 15 & 0.036 & 0.114 \\
\hline Perfluorodecanoic acid & Industrial chemical & & - & 8.24 & $\begin{array}{l}\mathbf{5 1 3} \\
469\end{array}$ & 15 & 0.021 & 0.055 \\
\hline $\begin{array}{l}\text { Perfluorononanoic } \\
\text { acid }\end{array}$ & Industrial chemical & & - & 7.88 & $\begin{array}{l}\mathbf{4 6 3} \\
419\end{array}$ & 15 & 0.010 & 0.020 \\
\hline Perfluorooctanoic acid & Industrial chemical & & - & 7.39 & $\begin{array}{l}\mathbf{4 1 3} \\
369\end{array}$ & 15 & 0.023 & 0.075 \\
\hline $\begin{array}{l}\text { Perfluoroheptanoic } \\
\text { acid }\end{array}$ & Industrial chemical & & - & 6.82 & $\begin{array}{l}363 \\
319\end{array}$ & 15 & 0.025 & 0.08 \\
\hline
\end{tabular}

LOD $=$ Limit of Detection $\mathrm{LOQ}=$ Limit of quantification. 
Table 3

Correlation coefficients $\left(\mathrm{r}^{2}\right)$ and recoveries (\%) of analytes.

\begin{tabular}{|c|c|c|c|c|c|}
\hline \multicolumn{2}{|l|}{ Compounds } & \multicolumn{4}{|c|}{ Recovery (\%) } \\
\hline & $r^{2}$ & Panga & Bonito & Hottentot & Snoek \\
\hline PFUnDA & 0.997 & $107.5 \pm 1.3$ & $85.3 \pm 4.0$ & $69.2 \pm 2.6$ & $89.2 \pm 2.3$ \\
\hline PFDA & 0.994 & $95.1 \pm 2.7$ & $90.6 \pm 3.4$ & $101.9 \pm 1.8$ & $98.2 \pm 2.7$ \\
\hline PFNA & 0.991 & $100.6 \pm 0.5$ & $99.7 \pm 1.8$ & $99.2 \pm 3.5$ & $102.7 \pm 3.2$ \\
\hline PFOA & 0.999 & $100.5 \pm 1.2$ & $99.5 \pm 0.9$ & $103.2 \pm 0.2$ & $101.9 \pm 4.0$ \\
\hline PFHpA & 0.992 & $96.8 \pm 1.6$ & $93.6 \pm 0.6$ & $99.6 \pm 3.4$ & $100.2 \pm 0.8$ \\
\hline diclofenac & 0.999 & $94.1 \pm 3.0$ & $92.7 \pm 1.5$ & $88.9 \pm 2.9$ & $98.5 \pm 0.8$ \\
\hline Sulfamethoxazole & 0.996 & $90.5 \pm 2.9$ & $87.3 \pm 0.3$ & $86.4 \pm 0.8$ & $83.9 \pm 2.4$ \\
\hline Phenytoin & 0.998 & $70.5 \pm 0.9$ & $78.0 \pm 2.1$ & $71.2 \pm 1.6$ & $74.3 \pm 2.3$ \\
\hline carbamazepine & 0.989 & $84.1 \pm 0.4$ & $78.7 \pm 3.6$ & $74.9 \pm 2.2$ & $89.5 \pm 3.1$ \\
\hline Lamivudine & 0.998 & $81.9 \pm 2.5$ & $90.8 \pm 4.1$ & $78.9 \pm 1.9$ & $89.9 \pm 0.5$ \\
\hline Caffeine & 0.989 & $79.3 \pm 1.4$ & $89.7 \pm 2.9$ & $75.6 \pm 0.3$ & $68.8 \pm 0.9$ \\
\hline acetaminophen & 0.998 & $89.2 \pm 2.0$ & $78.2 \pm 2.3$ & $92.5 \pm 0.1$ & $79.5 \pm 3.9$ \\
\hline Triclosan & 0.999 & $70.8 \pm 3.1$ & $77.5 \pm 1.3$ & $88.5 \pm 3.3$ & $85.2 \pm 2.5$ \\
\hline Bisphenol A & 0.993 & $71.3 \pm 2.3$ & $69.5 \pm 0.4$ & $74.4 \pm 2.6$ & $72.6 \pm 0.2$ \\
\hline 2-nitrophenol & - & nd & nd & nd & nd \\
\hline
\end{tabular}

Table 4

Comparison of PFAs compounds in fish samples obtained in this study with others in previously published studies.

\begin{tabular}{|c|c|c|c|c|c|c|}
\hline Location/Compound & PFUnDA & PFDA & PFNA & PFOA & PFHpA & Reference \\
\hline Hong kong & 0.71 & - & 0.65 & - & - & Zhao et al. (2011) \\
\hline Xiamen & 0.59 & 0.60 & 0.86 & 1.0 & - & Zhao et al. (2011) \\
\hline Brazil & $<3.0$ & $<1.19$ & $<1.41$ & 1.63 & 2.34 & Quinete et al. (2009) \\
\hline West coast of Korea & 0.04 & 0.05 & 0.02 & 0.06 & 0.23 & Naile et al. (2013) \\
\hline North Carolina, USA & 6.72 & 15.0 & - & - & - & Delinsky et al. (2010) \\
\hline Greece & 1.05 & 0.65 & 0.60 & - & - & Vassiliadou et al. (2015) \\
\hline China & 1.85 & 1.22 & - & $<0.5$ & - & Shi et al. (2010b) \\
\hline New York, USA & - & - & - & 5.2 & - & Sinclair et al. (2006) \\
\hline Spain & 0.71 & $<0.06$ & 0.51 & 0.09 & $<0.08$ & Domingo et al. (2012) \\
\hline Ohio, USA & 3.50 & 1.79 & 0.74 & $<0.20$ & 0.64 & Ye et al. (2008) \\
\hline Germany & nd & nd & nd & 2.3 & nd & Hölzer et al. (2011) \\
\hline This study & 124.4 & 78.86 & 49.53 & 37.52 & 83.86 & \\
\hline
\end{tabular}

from Guanabara Bay, Brazil and the concentration were quite lower compared to our result in this study $(3.4 \mathrm{ng} / \mathrm{g}$ ). The fillet has the lowest concentration of all the compounds; PFUnDA was not detected in any of the fish parts. The overall distribution of PFCs in hottentot fish followed the order intestine $>$ liver $>$ gills $>$ fillet.

In snoek fish, PFUnDA was only found in the gills with a concentration of $75.18 \mathrm{ng} / \mathrm{g}$. PFDA, PFNA and PFHpA were detected in all the parts with gills having the highest concentration of $106.8 \mathrm{ng} /$ g, $114.0 \mathrm{ng} / \mathrm{g}, 138.3 \mathrm{ng} / \mathrm{g}$ respectively while the concentration in other parts ranged from 20.13 to $28.33 \mathrm{ng} / \mathrm{g}, 21.22-23.74 \mathrm{ng} / \mathrm{g}$ and 40.06-110.2 ng/g respectively. PFOA was only detected in the fillet and gills with a concentration of $26.07 \mathrm{ng} / \mathrm{g}$ and $45.01 \mathrm{ng} / \mathrm{g}$ respectively. The overall distribution of PFCs in snoek fish followed the order gills $>$ fillet $>$ intestine $>$ liver.

Overall, hottentot had the highest concentration of PFDA and PFOA of $179.2 \mathrm{ng} / \mathrm{g}$ and $63.17 \mathrm{ng} / \mathrm{g}$ respectively, snoek had the highest concentration of PFNA of $114.0 \mathrm{ng} / \mathrm{g}$, bonito had the highest concentration of PFHpA of $297.5 \mathrm{ng} / \mathrm{g}$. In a study conducted in Xiamen and Hong Kong, PFDA, PFNA, PFUnDA, and PFOA were determine in three marine fish and three freshwater fish, the concentration obtained from the study $(0.33-0.71 \mathrm{ng} / \mathrm{g})$ were quite lower to the concentration from this present study (Zhao et al., 2011) (Table 4) indicating that perfluoroalkyl compounds levels may be higher in fish species around the marine environment of Cape Town, South Africa compared to the marine environment in other parts of the world. This shows that marine water in Cape Town, South Africa contains high levels of perfluoroalkyl compounds.

Moreover, PFUnDA was found only in panga fish, whereas hottentot fish had the highest concentration of PFDA and PFOA, in addition, PFOA had the lowest concentration across the fish species. Snoek fish had the highest concentration of PFNA, and bonito fish had the highest concentration of PFHpA. Although there was no specific trend in the concentration of perfluorinated compounds in each fish part of all fish species tested in this study, there were significant amounts of these contaminants in all fish parts. These results indicate that perfluoroalkyl compounds bioaccumulate in all fish parts.

\subsection{Pharmaceutical compounds}

In the panga fish diclofenac, phenytoin and carbamazepine was only detected in the fillet with a concentration of $551.8 \mathrm{ng} / \mathrm{g}$, $55.67 \mathrm{ng} / \mathrm{g}$ and $22.90 \mathrm{ng} / \mathrm{g}$ respectively while sulfamethoxazole and caffeine was only detected in the intestine, gills and liver with a concentration of $28.55 \mathrm{ng} / \mathrm{g}$ and $2.030 \mathrm{ng} / \mathrm{g}$ respectively. In a study conducted by Wang and Gardinali (2012), the concentration of caffeine and carbamazepine in fish $(0.81 \mathrm{ng} / \mathrm{g}$ and $0.1 \mathrm{ng} / \mathrm{g}$ respectively) was lower to the one obtained in this study. Also from Kim et al. (2017) the concentration of caffeine $(1.36 \mathrm{ng} / \mathrm{g}$ ) was quite lower to our study. Acetaminophen was detected in all the parts with liver having the highest concentration of $33.26 \mathrm{ng} / \mathrm{g}$ and other parts ranged from 17.95 to $30.26 \mathrm{ng} / \mathrm{g}$.

In bonito fish, diclofenac, phenytoin and acetaminophen were not detected in any of the fish parts, sulfamethoxazole and caffeine were only detected in the fillet and liver with a concentration of $385.2 \mathrm{ng} / \mathrm{g}$ and $50.49 \mathrm{ng} / \mathrm{g}, 36.34 \mathrm{ng} / \mathrm{g}$ and $64.78 \mathrm{ng} / \mathrm{g}$ respectively. Caffeine was only detected in the gills with a concentration of $22.83 \mathrm{ng} / \mathrm{g}$. Moreno-González et al. (2016) report the concentration of diclofenac and carbamazepine in fish to be $29 \mathrm{ng} / \mathrm{g}$ and $6.4 \mathrm{ng} / \mathrm{g}$, 
comparing this result to our study, this was quite lower.

In hottentot fish, diclofenac and sulfamethoxazole were detected in all the fish parts with the fillet having the highest concentration of $920.5 \mathrm{ng} / \mathrm{g}$ and $88.53 \mathrm{ng} / \mathrm{g}$ respectively while phenytoin was detected in all parts but with liver having the highest concentration of $129.38 \mathrm{ng} / \mathrm{g}$. The concentration in other parts ranged from 716.2 to $906.2 \mathrm{ng} / \mathrm{g}, 75.25-79.12 \mathrm{ng} / \mathrm{g}$ and $107.7-119.4 \mathrm{ng} / \mathrm{g}$ for diclofenac, sulfamethoxazole and phenytoin respectively. By comparison, the highest concentration of sulfamethoxazole in our study is higher than those $(0.95 \mathrm{ng} / \mathrm{g})$ reported in the tissue of hake fish in Spain (Fernandez-Torres et al., 2010) and in a study reported by Li et al. (2012b) in North China $(2.15 \mathrm{ng} / \mathrm{g})$ while in a study from Laizhou Bay, North China the concentration of sulfamethoxazole $(40-110 \mathrm{ng} / \mathrm{g})$ in some fish organs were similar and other were lower compared to our study (Liu et al., 2018).

In snoek fish, diclofenac was detected in all the parts with the fillet having the highest concentration of $1812 \mathrm{ng} / \mathrm{g}$ while the concentration in other parts ranged from 1089 to $1125 \mathrm{ng} / \mathrm{g}$. Caffeine and acetaminophen were not detected in any of the fish parts while carbamazepine was only detected in the fillet with a concentration of $5.160 \mathrm{ng} / \mathrm{g}$. Sulfamethoxazole and phenytoin were detected only in fillet, intestine and liver with a concentration range of $88.63-688.6 \mathrm{ng} / \mathrm{g}$ and $137.4-222.2 \mathrm{ng} / \mathrm{g}$ respectively. The concentration of carbamazepine, acetaminophen and diclofenac reported in a study conducted by Dasenaki et al. (2015) in fish ( $20 \mathrm{ng} / \mathrm{g}$ for each compound) were also lower compared to this study.

Overall diclofenac had the highest concentration out of all the pharmaceutical compounds while sulfamethoxazole was the most dominant in the fish samples which was detected in at least in one part of all the fish species. Acetaminophen was only detected in panga fish and hottentot fish while caffeine was detected only in panga fish, bonito fish and hottentot fish. Carbamazepine was detected in at least in one part of all of the fish samples while phenytoin was detected in only panga fish, hottentot fish and snoek fish.

Although there is no specific trend in the concentration of pharmaceutical compounds in each fish part of all the fish species in this study, there was a significant amount of these diverse contaminants in all fish parts. Also, worthy of note is the concentration of these contaminants in the different parts/organs of panga and hottentot fish were the same, this could be attributed to the similarity observed in the size of these two fish species (Table 1) as compared to that of snoek and bonito fish species. A previous study has reported that pharmaceuticals in fish can reach significantly higher concentrations in plasma than in ambient water (Fent et al., 2006). These results indicate that pharmaceuticals compounds bioaccumulate in all fish parts. Other fish species have shown similar bioaccumulation of diverse compound (Álvarez-Muñoz et al., 2015; Kim et al., 2017; Moreno-González et al., 2016; Wang and Gardinali, 2012). However, the maximum concentrations found in our study were higher than those in the aforementioned studies. Furthermore, publications reporting PPCPs in fish from freshwater species includes (Chu and Metcalfe, 2007; Du et al., 2014; Garcia et al., 2012; Huerta et al., 2013; Ramirez et al., 2007; Tanoue et al., 2014; Togunde et al., 2012) and fish from brackish water, usually contaminated rivers (Fick et al., 2010; Gelsleichter and Szabo, 2013; Kolpin et al., 2002) this proofs the existence of this compounds in different water bodies worldwide.

Bioaccumulation in fish can be achieved from water through the gills, skin, and food, resulting in enhanced levels of pollutant in fish tissue. Generally, feeding preference, general behaviour, amount of body lipid, and trophic level of fish are considered as factors affecting bioaccumulation. Moreover, the ecological characteristics of fish play a significant role in the bioaccumulation of these pollutants.

To sum up, exposure of organisms to biologically active chemicals in urban sewage effluents does not solely affect vertebrates. In some cases, there is greater sensitivity in invertebrates, microbes, and plants than in fish, which can change the entire community structure (Waiser et al., 2011).

Nevertheless, more complete experimental design, such as laboratory controls and field controls, should be employed to determine persistent organic pollutants in fish in future work.

\subsection{Risk assessment}

The impact of pollutants in different fish species was evaluated using risk quotient method, $\mathrm{LC}_{50}$ and NOEC were used to find the level of toxicity from the acute and chronic ecotoxicity testing. Table 6 shows the respective risk quotients the results obtained for the PPCP and PFC in fish. The level of concern for both acute and chronic risk are 0.5 and 1.0 respectively. For chronic risk, then $\mathrm{RQ}<1.0$, shows no chronic risk concern but if higher, there is a chronic risk. Also, for acute risk, then $\mathrm{RQ}<0.5$, shows no high acute risk concern (US EPA, 2016). From Table 5, lamivudine, triclosan, bisphenol A and 2-nitrophenol were not detected in any of the fish species therefore, the risk quotient was zero.

For the risk quotients for perfluorinated compounds in panga fish type, PFUnDA shows high acute and chronic risk with high values of 2.1 and 6.2 respectively in the fillet which had the highest values out of all the compounds while it was not detected in other organs (gills, liver and intestine). PFDA, PFHpA and PFNA were observed to be a high acute and chronic risk concern in all organs of the fish while PFOA showed a high acute and chronic risk in the fillet, and low risk in liver, intestine and gills of the fish. All the compounds showed a high risk, both acute and chronic, in the fillet parts of the fish which is the part humans consume. For pharmaceutical compounds, diclofenac showed a very high acute and chronic risk in the fillet with values of 14.2 and 42.6 respectively while sulfamethoxazole showed low acute and high chronic risk in the gills, liver and intestine but was not detected in the fillet of the fish. Similar results have been reported for Sulfamethoxazole to pose a high risk to aquatic organisms (Du et al., 2017; Xu et al., 2013; Zhang et al., 2013). Phenytoin was observed to be of high acute and chronic risk concern only in the fillet of the fish while carbamazepine showed low acute and high chronic risk in the fillet but was not detected in other organs of the fish. Caffeine showed low acute and chronic risk in the gills, liver and intestine but was not detected in the fillet of the fish while acetaminophen showed low acute and chronic risk in the fillet but high acute and chronic risk in the gills, liver and intestine of the fish. Lamivudine was not detected in any of the fish organs.

As a result of their widespread and high usage, these chemicals and pharmaceuticals have a more constant presence, although in low concentrations, in surface and marine water-bodies and this has been reported by several authors (Birch et al., 2015; Gulkowska et al., 2007; Lam et al., 2014; Yang et al., 2011; Zhang et al., 2013). It is not likely that drugs will affect aquatic organisms in the same manner that they affect humans, for example, $\beta$-blockers cannot pharmacodynamically affect organisms which lack $\beta$-adrenoreceptors (CSTEE, 2001). Notwithstanding, because of their persistent low occurrence, these compounds will probably have chronic, rather than acute toxic, effects, like causing a change in behaviour that reduces the individual fitness of an organism (Jones et al., 2002).

In bonito fish, for perfluorinated compounds: PFUnDA was not detected in any of the fish organs. PFDA showed high acute and chronic risk in the fillet, gills and liver and low acute and chronic risk in the intestine of the fish. PFNA was observed to be of high 
acute and chronic risk concern in the fillet, gills and liver and low acute and high chronic risk in the intestine of the fish. PFOA showed a high acute and chronic risk in the intestine, and low risk in gills of the fish but was not detected in the fillet and liver of the fish. PFHpA shows high acute and chronic risk in all the fish organs (fillet, gills, intestine and liver). For pharmaceutical compounds, diclofenac, phenytoin, acetaminophen and lamivudine was not detected so the risk quotient was zero. Sulfamethoxazole showed very high acute and chronic risk in the fillet and liver with values of 6.4 and 19.3, 6.0 and 18.0 respectively while carbamazepine showed a low acute but high chronic risk in the gills of the fish. Caffeine was observed to be of high acute and chronic risk concern in the fillet and liver of the fish while it was not detected in the gills and intestine of the fish.

In hottentot fish, for perfluorinated compounds: PFUnDA was not detected in any of the fish organs. PFDA and PFHpA were observed to be a high acute and chronic risk concern in all organs of the fish while PFOA and PFNA showed a high acute and chronic risk in the intestine, gills and liver of the fish and low risk in the fillet of the fish. For pharmaceutical compounds, diclofenac showed a very high acute and chronic risk in all the fish organs with values range from 11.9 to 15.3 and $35.8-46.0$ respectively while sulfamethoxazole and phenytoin were observed to be of high acute and chronic risk concern in all the fish organs. Carbamazepine, acetaminophen and caffeine showed low acute and chronic risk in the gills, liver and intestine but was not detected in the fillet of the fish while lamivudine was not detected in any of the fish organs.

In snoek fish, for perfluorinated compounds: PFUnDA showed a high acute and chronic risk with values of 1.3 and 3.6 respectively in the gills while it was not detected in other organs (fillet, liver and intestine). PFDA and PFNA showed high acute and chronic risk only in the gills with low acute but high chronic risk in the intestine, liver and fillet of the fish. PFOA showed a high acute and chronic risk in the gills as well as a low acute but high chronic risk in the fillet of the fish but was not detected in the intestine and liver of the fish. PFHpA was observed to be a high acute and chronic risk concern in all the fish organs (fillet, gills, intestine and liver). For pharmaceutical compounds, diclofenac showed a very high acute and chronic risk in all the fish organs with values range from 18.2 to 30.2 and 54.5-90.6 respectively with the fillet having the highest values. Caffeine, acetaminophen and lamivudine were not detected so the risk quotient was zero. Sulfamethoxazole and phenytoin showed very high acute and chronic risk in the fillet, intestine and liver but was not detected in the gills of the fish, while carbamazepine showed a low acute and chronic risk in the fillet and was not detected in the remaining organs of the fish. Results from screening the risk level characterization in the fish samples showed high acute and chronic risk for some of the investigated compounds, implying that significant impacts on seawater fish species are likely and so is the associated risk. Hence, further perfluorinated compounds and PPCP occurrence, exposure and toxicological input (especially for long-term (chronic) effects on organisms and possible effects of combined exposure to multiple compounds) is required for better understanding of their possible adverse effects to non-target organisms and in order to provide a more comprehensive picture of their combined risk and impact upon the oceanic environment. These fish are wild caught by small commercial fishing vessels that are stationed at Kalk Bay harbour. The high degree of contamination found in fish that are free swimming in the pelagic zone around the coastal waters of the Western Cape should be cause for alarm since the pollution can only be due to the poor sewage disposal practiced by the city as these compounds are almost all human excretion and effluents being discharged into the marine environment (CSIR, 2017; Petrik et al., 2017).

\section{Conclusion}

Emerging organic contaminants are ubiquitous in the environment and South Africa marine environments are not an exemption as it was demonstrated by the presence of many of these compounds in the different fish species. This study showed that the method used is capable of detecting low parts per billion concentrations in different fish species, which was also the case in our previous study (Petrik et al., 2017). Application of these methods indicated that diverse chemicals including (PFAs) and several PPCPs are present in fish samples and significantly accumulated in them. In summary, this study demonstrates that diverse commonly prescribed human pharmaceuticals and perfluoroalkyl compounds are present at detectable, even quantifiable concentrations in fish and fish organs/parts. This study showed that these chemical concentrations are greatly related to anthropogenic activities, including sewage discharge which all contribute to these chemicals finding their way into the oceanic environment thereby accumulating in various edible fish species inhabiting the oceanic environment.

The results obtained showed that diverse synthetic compounds such as PFDA, PFNA and PFHpA were the most predominant among the perfluoroalkyl compounds range: (20.13-179.2 $\mathrm{ng} / \mathrm{g}$ ), $(21.22-114.0 \mathrm{ng} / \mathrm{g}$ ) and $(40.06-138.3 \mathrm{ng} / \mathrm{g})$. Also, diclofenac (an analgesic compound) has the highest concentration out of all the pharmaceuticals detected (range: $551.8-1812.3 \mathrm{ng} / \mathrm{g}$ ) and sulfamethoxazole (an antibiotics medication) was dominant in all the fish samples. These compounds were simultaneously found in the fish tested.

Risk assessment of these pollutants on aquatic organisms suggested that higher animals and humans who consume these species of fish could be at risk of ingesting diverse compounds. In addition, a risk assessment based on the calculated risk quotient (RQ) showed that those compounds present in all the fish species could pose high $(\mathrm{RQ}>1)$ risks to sensitive aquatic microorganisms and humans who consume these contaminated seafoods would be at risk.

Our results show that chemical compounds and drugs can remain bioavailable for aquatic organisms for long time periods (weeks to months to years) and even re-enter the food web at a later time. As such, for an understanding of accumulation and dispersion of pharmaceuticals in aquatic food webs, detailed ecological knowledge is required. Information on PFAs and PPCPs in fish to date indicate that an additional understanding of PFAs and PPCP accumulation in aquatic life at a broad scale and in pelagic fish is necessary to support future efforts in characterizing ecological and human health risks of diverse chemical compounds in the oceanic environment. Finally, their simultaneous presence in fish indicates that many other synthetic chemical compounds may also be bioaccumulating in these and other marine species that are part of commercially exploited catches.

\section{Acknowledgments}

We acknowledge NRF for the NRF rated scientist funds and UWC for the SR funds received for this study. We are indebted to the laboratories at Stellenbosch University, Central Analytical Facilities (CAF) and the University of the Western Cape, Environmental and Nano Science Group (ENS).

\section{Appendix A. Supplementary data}

Supplementary data to this article can be found online at https://doi.org/10.1016/j.envpol.2019.05.091. 


\section{References}

Álvarez-Muñoz, D., Rodríguez-Mozaz, S., Maulvault, A.L., Tediosi, A., FernándezTejedor, M., Van den Heuvel, F., Kotterman, M., Marques, A., Barceló, D., 2015. Occurrence of pharmaceuticals and endocrine disrupting compounds in macroalgaes, bivalves, and fish from coastal areas in Europe. Environ. Res. 143, 56-64. https://doi.org/10.1016/j.envres.2015.09.018.

Álvarez-Ruiz, R., Picó, Y., 2019. Sequential window acquisition of all theoretical fragments versus information dependent acquisition for suspected-screening of pharmaceuticals in sediments and mussels by ultra-high pressure liquid chromatography-quadrupole time-of-flight-mass spectrometr. J. Chromatogr. A 1595, 81-90. https://doi.org/10.1016/j.chroma.2019.02.041.

Arpin-Pont, L., Martínez-Bueno, M.J., Gomez, E., Fenet, H., 2016. Occurrence of PPCPs in the marine environment: a review. Environ. Sci. Pollut. Res. 23, 4978-4991. https://doi.org/10.1007/s11356-014-3617-x.

Birch, G.F., Drage, D.S., Thompson, K., Eaglesham, G., Mueller, J.F., 2015. Emerging contaminants (pharmaceuticals, personal care products, a food additive and pesticides) in waters of Sydney estuary, Australia. Mar. Pollut. Bull. 97, 56-66. https://doi.org/10.1016/j.marpolbul.2015.06.038.

Bringolf, R.B., Heltsley, R.M., Newton, T.J., Eads, C.B., Fraley, S.J., Shea, D., Cope, W.G., 2010. Environmental occurrence and reproductive effects of the pharmaceutical fluoxetine in native freshwater mussels. Environ. Toxicol. Chem. 29, 1311-1318. https://doi.org/10.1002/etc.157.

Bueno, M.M.J., Boillot, C., Munaron, D., Fenet, H., Casellas, C., Gómez, E., 2014 Occurrence of venlafaxine residues and its metabolites in marine mussels at trace levels: development of analytical method and a monitoring program. Anal. Bioanal. Chem. 406, 601-610. https://doi.org/10.1007/s00216-013-7477-x.

Cabello, F.C., 2006. Heavy use of prophylactic antibiotics in aquaculture: a growing problem for human and animal health and for the environment. Environ. Microbiol. 8, 1137-1144. https://doi.org/10.1111/j.1462-2920.2006.01054.x.

Chen, H., Liu, S., Xu, X.R., Liu, S.S., Zhou, G.J., Sun, K.F., Zhao, J.L., Ying, G.G., 2015. Antibiotics in typical marine aquaculture farms surrounding Hailing Island, South China: occurrence, bioaccumulation and human dietary exposure. Mar. Pollut. Bull. 90, 181-187. https://doi.org/10.1016/j.marpolbul.2014.10.053.

Chen, H., Liu, S., Xu, X.R., Diao, Z.H., Sun, K.F., Hao, Q.W., Liu, S.S., Ying, G.G., 2018. Tissue distribution, bioaccumulation characteristics and health risk of antibiotics in cultured fish from a typical aquaculture area. J. Hazard Mater. 343, 140-148. https://doi.org/10.1016/j.jhazmat.2017.09.017.

Chu, S., Metcalfe, C.D., 2007. Analysis of paroxetine, fluoxetine and norfluoxetine in fish tissues using pressurized liquid extraction, mixed mode solid phase extraction cleanup and liquid chromatography-tandem mass spectrometry. J. Chromatogr. A 1163, 112-118, https://doi.org/10.1016/j.chroma 2007.06.014.

Compton, J.S., 2004. The Rocks and Mountains of Cape Town, in: Double Storey Books, pp. 24-26, 44-70.

CSIR, 2017. Cape Town Outfalls Monitoring Programme: Surveys Made in 2015 2016. CSIR Report CSIR/NRE/ECOS/IR/2017/0035/B. Cape Town.

CSTEE, SCIENTIFIC COMMITTEE ON TOXICITY, E.A.T.E., 2001. Draft CPMP Discussion Paper on Environmental Risk Assessment of Medicinal Products for Human Use [ Non-genetically Modified Organism ( Non-GMO ). Containing ] 1-22.

Dasenaki, M.E., Bletsou, A.A., Koulis, G.A., Thomaidis, N.S., 2015. Qualitative multiresidue screening method for 143 veterinary drugs and pharmaceuticals in milk and fish tissue using liquid chromatography quadrupole-time-of-flight mass spectrometry. J. Agric. Food Chem. 63, 4493-4508. https://doi.org/10.1021/acs. jafc.5b00962.

Daughton, C.G., Ternes, T.A., 1999. Pharmaceuticals and personal care products in the environment: agents of subtle change? Environ. Health Perspect. 107, 907.

de Solla, S.R., Gilroy, Ė.A.M., Klinck, J.S., King, L.E., McInnis, R., Struger, J., Backus, S.M., Gillis, P.L., 2016. Bioaccumulation of pharmaceuticals and personal care products in the unionid mussel Lasmigona costata in a river receiving wastewater effluent. Chemosphere 146, 486-496. https://doi.org/10.1016/J. CHEMOSPHERE.2015.12.022.

Delinsky, A.D., Strynar, M.J., McCann, P.J., Varns, J.L., McMillan, L., Nakayama, S.F., Lindstrom, A.B., 2010. Geographical distribution of perfluorinated compounds in fish from Minnesota lakes and rivers. Environ. Sci. Technol. 44, 2549-2554. https://doi.org/10.1021/es903777s.

Domingo, J.J., Ericson-Jogsten, I., Perelló, G.P., Nadal, M., Van Bavel, B., Kä, A., 2012. Human exposure to perfluorinated compounds in Catalonia, Spain: contribution of drinking water and fish and shellfish. https://doi.org/10.1021/jf300355c.

Du, B., Haddad, S.P., Luek, A., Scott, W.C., Saari, G.N., Kristofco, L.A., Connors, K.A., Rash, C., Rasmussen, J.B., Chambliss, C.K., Brooks, B.W., 2014. Bioaccumulation and trophic dilution of human pharmaceuticals across trophic positions of an effluent-dependent wadeable stream. Philos. Trans. R. Soc. B Biol. Sci. 369, 20140058-20140058. https://doi.org/10.1098/rstb.2014.0058.

Du, B., Haddad, S.P., Luek, A., Scott, W.C., Saari, G.N., Burket, S.R., Breed, C.S., Kelly, M., Broach, L., Rasmussen, J.B., Chambliss, C.K., Brooks, B.W., 2016. Bioaccumulation of human pharmaceuticals in fish across habitats of a tidally influenced urban bayou. Environ. Toxicol. Chem. 35, 966-974. https://doi.org/ $10.1002 /$ etc.3221.

Du, J., Zhao, H., Liu, S., Xie, H., Wang, Y., Chen, J., 2017. Antibiotics in the coastal water of the South Yellow Sea in China: occurrence, distribution and ecological risks. Sci. Total Environ. 595, 521-527. https://doi.org/10.1016/j.scitotenv.2017. 03.281.

EU Commission Decision, 2002. 96/23/EC COMMISSION DECISION of 12 August 2002 implementing Council Directive 96/23/EC concerning the performance of analytical methods and the interpretation of results (notified under document number C(2002) 3044)(Text withEEA relevance) (2002/657/EC). 96/23/EC Comm. Decis. 29. https://doi.org/10.1017/CBO9781107415324.004.

Fabbri, E., Franzellitti, S., 2016. Human pharmaceuticals in the marine environment: focus on exposure and biological effects in animal species. Environ. Toxicol. Chem. 35, 799-812. https://doi.org/10.1002/etc.3131.

Fent, K., Weston, A.A., Caminada, D., 2006. Ecotoxicology of human pharmaceuticals. Aquat. Toxicol. 76, 122-159. https://doi.org/10.1016/j.aquatox.2005.09.009.

Fernandez-Torres, R., Lopez, M.A.B., Consentino, M.O., Mochon, M.C., PerezBernal, J.L., 2010. Application of enzymatic probe sonication extraction for the determination of selected veterinary antibiotics and their main metabolites in fish and mussel samples. Anal. Chim. Acta 675, 156-164. https://doi.org/10. 1016/J.ACA.2010.07.026.

Fick, J., Lindberg, R.H., Parkkonen, J., Arvidsson, B., Tysklind, M., Joakim Larsson, D.G., 2010. Therapeutic levels of levonorgestrel detected in blood plasma of fish: results from screening rainbow trout exposed to treated sewage effluents. Environ. Sci. Technol. 44, 2661-2666. https://doi.org/10.1021/ es903440m.

Garcia, S.N., Foster, M., Constantine, L.A., Huggett, D.B., 2012. Field and laboratory fish tissue accumulation of the anti-convulsant drug carbamazepine. Ecotoxicol. Environ. Saf. 84, 207-211. https://doi.org/10.1016/J.ECOENV.2012.07.013.

Gaw, S., Thomas, K.V., Hutchinson, T.H., 2014. Sources, impacts and trends of pharmaceuticals in the marine and coastal environment. Philos. Trans. R. Soc. B Biol. Sci. 369, 20130572-20130572. https://doi.org/10.1098/rstb.2013.0572.

Gelsleichter, J., Szabo, N.J., 2013. Uptake of human pharmaceuticals in bull sharks (Carcharhinus leucas) inhabiting a wastewater-impacted river. Sci. Total Environ. 196-201, 456-457. https://doi.org/10.1016/J.SCITOTENV.2013.03.078.

Gilroy, È.A.M., Klinck, J.S., Campbell, S.D., McInnis, R., Gillis, P.L., de Solla, S.R., 2014 Toxicity and bioconcentration of the pharmaceuticals moxifloxacin, rosuvastatin, and drospirenone to the unionid mussel Lampsilis siliquoidea. Sci. Total Environ. 487, 537-544. https://doi.org/10.1016/j.scitotenv.2014.03.051.

Gilroy, È.A.M., Gillis, P.L., King, L.E., Bendo, N.A., Salerno, J., Giacomin, M., de Solla, S.R., 2017. The effects of pharmaceuticals on a unionid mussel ( Lampsilis siliquoidea ): an examination of acute and chronic endpoints of toxicity across life stages. Environ. Toxicol. Chem. 36, 1572-1583. https://doi.org/10.1002/etc. 3683.

Gomez, E., Bachelot, M., Boillot, C., Munaron, D., Chiron, S., Casellas, C., Fenet, H., 2012. Bioconcentration of two pharmaceuticals (benzodiazepines) and two personal care products (UV filters) in marine mussels (Mytilus galloprovincialis) under controlled laboratory conditions. Environ. Sci. Pollut. Res. 19, 2561-2569. https://doi.org/10.1007/s11356-012-0964-3.

Grabicova, K., Grabic, R., Fedorova, G., Fick, J., Cerveny, D., Kolarova, J., Turek, J., Zlabek, V., Randak, T., 2017. Bioaccumulation of psychoactive pharmaceuticals in fish in an effluent dominated stream. Water Res. 124, 654-662. https://doi. org/10.1016/J.WATRES.2017.08.018.

Gulkowska, A., He, Y., So, M.K., Yeung, L.W.Y., Leung, H.W., Giesy, J.P., Lam, P.K.S., Martin, M., Richardson, B.J., 2007. The occurrence of selected antibiotics in Hong Kong coastal waters. Mar. Pollut. Bull. 54, 1287-1293. https://doi.org/10.1016/j. marpolbul.2007.04.008.

Hedrick-Hopper, T.L., Koster, L.P., Diamond, S.L., 2015. Accumulation of triclosan from diet and its neuroendocrine effects in Atlantic croaker (Micropogonias undulatus) under two temperature Regimes. Mar. Environ. Res. 112, 52-60. https://doi.org/10.1016/J.MARENVRES.2015.09.006.

Hölzer, J., Göen, T., Just, P., Reupert, R., Rauchfuss, K., Kraft, M., Müller, J. Wilhelm, M., 2011. Perfluorinated compounds in fish and blood of anglers at Lake Möhne, Sauerland area, Germany. Environ. Sci. Technol. 45, 8046-8052. https://doi.org/10.1021/es104391z.

Huerta, B., Jakimska, A., Gros, M., Rodríguez-Mozaz, S., Barceló, D., 2013. Analysis of multi-class pharmaceuticals in fish tissues by ultra-high-performance liquid chromatography tandem mass spectrometry. J. Chromatogr. A 1288, 63-72. https://doi.org/10.1016/j.chroma.2013.03.001.

Jakimska, A., Huerta, B., Bargańska, Ż., Kot-Wasik, A., Rodríguez-Mozaz, S., Barceló, D., 2013. Development of a liquid chromatography-tandem mass spectrometry procedure for determination of endocrine disrupting compounds in fish from Mediterranean rivers. J. Chromatogr. A 1306, 44-58. https://doi. org/10.1016/J.CHROMA.2013.07.050.

Jin, X., Peldszus, S., 2012. Selection of representative emerging micropollutants for drinking water treatment studies: a systematic approach. Sci. Total Environ. 414, 653-663. https://doi.org/10.1016/j.scitotenv.2011.11.035.

Johnson, L.L., Lomax, D.P., Myers, M.S., Olson, O.P., Sol, S.Y., O'Neill, S.M., West, J. Collier, T.K., 2008. Xenoestrogen exposure and effects in English sole (Parophrys vetulus) from Puget Sound. WA. Aquat. Toxicol. 88, 29-38. https://doi.org/10. 1016/j.aquatox.2008.03.001.

Jones, O.A.H., Voulvoulis, N., Lester, J.N., 2002. Aquatic environmental assessment of the top 25 English prescription pharmaceuticals. Water Res. 36, 5013-5022. https://doi.org/10.1016/S0043-1354(02)00227-0.

Kalachova, K., Pulkrabova, J., Cajka, T., Drabova, L., Stupak, M., Hajslova, J., 2013. Gas chromatography-triple quadrupole tandem mass spectrometry: a powerful tool for the (ultra)trace analysis of multiclass environmental contaminants in fish and fish feed. Anal. Bioanal. Chem. 405, 7803-7815. https://doi.org/10 1007/s00216-013-7000-4.

Kim, H.Y., Lee, I.S., Oh, J.E., 2017. Human and veterinary pharmaceuticals in the marine environment including fish farms in Korea. Sci. Total Environ. 579, 940-949. https://doi.org/10.1016/j.scitotenv.2016.10.039.

Klosterhaus, S.L., Grace, R., Hamilton, M.C., Yee, D., 2013. Method validation and 
reconnaissance of pharmaceuticals, personal care products, and alkylphenols in surface waters, sediments, and mussels in an urban estuary. Environ. Int. 54, 92-99. https://doi.org/10.1016/j.envint.2013.01.009.

Kolpin, D.W., Furlong, E.T., Meyer, M.T., Thurman, E.M., Zaugg, S.D., Barber, L.B. Buxton, H.T., 2002. Pharmaceuticals, hormones, and other organic wastewate contaminants in U.S. Streams, 1999-2000: a national reconnaissance. Environ. Sci. Technol. 36, 1202-1211. https://doi.org/10.1021/es011055j.

Lacaze, E., Pédelucq, J., Fortier, M., Brousseau, P., Auffret, M., Budzinski, H. Fournier, M., 2015. Genotoxic and immunotoxic potential effects of selected psychotropic drugs and antibiotics on blue mussel (Mytilus edulis) hemocytes. Environ. Pollut. 202, 177-186. https://doi.org/10.1016/J.ENVPOL.2015.03.025.

Lam, N.-H., Cho, C.-R., Lee, J.-S., Soh, H.-Y., Lee, B.-C., Lee, J.-A., Tatarozako, N. Sasaki, K., Saito, N., Iwabuchi, K., Kannan, K., Cho, H.-S., 2014. Perfluorinated alkyl substances in water, sediment, plankton and fish from Korean rivers and lakes: a nationwide survey. Sci. Total Environ. 491-492, 154-162. https://doi. org/10.1016/J.SCITOTENV.2014.01.045.

Li, W., Shi, Y., Gao, L., Liu, J., Cai, Y., 2012a. Investigation of antibiotics in mollusks from coastal waters in the Bohai Sea of China. Environ. Pollut. 162, 56-62. https://doi.org/10.1016/j.envpol.2011.10.022.

Li, W., Shi, Y., Gao, L., Liu, J., Cai, Y., 2012b. Occurrence of antibiotics in water, sediments, aquatic plants, and animals from Baiyangdian Lake in North China. Chemosphere 89, 1307-1315. https://doi.org/10.1016/j.chemosphere.2012.05. 079 .

Liu, J., Wang, R., Huang, B., Lin, C., Wang, Y., Pan, X., 2011. Distribution and bioaccumulation of steroidal and phenolic endocrine disrupting chemicals in wild fish species from Dianchi Lake, China. Environ. Pollut. 159, 2815-2822. https:/ doi.org/10.1016/J.ENVPOL.2011.05.013.

Liu, S., Chen, H., Xu, X.-R., Hao, Q.-W., Zhao, J.-L., Ying, G.-G., 2017a. Three classes of steroids in typical freshwater aquaculture farms: comparison to marine aquaculture farms. Sci. Total Environ. 609, 942-950. https://doi.org/10.1016/J SCITOTENV.2017.07.207.

Liu, S., Xu, X.-R., Qi, Z.-H., Chen, H., Hao, Q.-W., Hu, Y.-X., Zhao, J.-L., Ying, G.-G., 2017b. Steroid bioaccumulation profiles in typical freshwater aquaculture environments of South China and their human health risks via fish consumption. Environ. Pollut. 228, 72-81. https://doi.org/10.1016/J.ENVPOL.2017.05.031.

Liu, S., Bekele, T.-G., Zhao, H., Cai, X., Chen, J., 2018. Bioaccumulation and tissue distribution of antibiotics in wild marine fish from Laizhou Bay, North China. Sci. Total Environ. 631-632, 1398-1405. https://doi.org/10.1016/J.SCITOTENV. 2018.03.139.

Malinsky, M.D., Jacoby, C.B., Reagen, W.K., 2011. Determination of perfluorinated compounds in fish fillet homogenates: method validation and application to fillet homogenates from the Mississippi River. Anal. Chim. Acta 683, 248-257. https://doi.org/10.1016/J.ACA.2010.10.028.

McEneff, G., Barron, L., Kelleher, B., Paull, B., Quinn, B., 2014. A year-long study of the spatial occurrence and relative distribution of pharmaceutical residues in sewage effluent, receiving marine waters and marine bivalves. Sci. Total Environ. 317-326, 476-477. https://doi.org/10.1016/j.scitotenv.2013.12.123.

Montesdeoca-Esponda, S., Checchini, L., Del Bubba, M., Sosa-Ferrera, Z., SantanaRodriguez, J.J., 2018. Analytical approaches for the determination of personal care products and evaluation of their occurrence in marine organisms. Sci. Total Environ. 633, 405-425. https://doi.org/10.1016/J.SCITOTENV.2018.03.182.

Moreno-González, R., Rodríguez-Mozaz, S., Huerta, B., Barceló, D., León, V.M., 2016. Do pharmaceuticals bioaccumulate in marine molluscs and fish from a coasta lagoon? Environ. Res. 146, 282-298. https://doi.org/10.1016/j.envres.2016.01. 001.

Mottaleb, M.A., Usenko, S., O'Donnell, J.G., Ramirez, A.J., Brooks, B.W., Chambliss, C.K., 2009. Gas chromatography-mass spectrometry screening methods for select UV filters, synthetic musks, alkylphenols, an antimicrobia agent, and an insect repellent in fish. J. Chromatogr. A 1216, 815-823. https:/ doi.org/10.1016/j.chroma.2008.11.072.

Nácher-Mestre, J., Serrano, R., Hernández, F., Benedito-Palos, L., Pérez-Sánchez, J. 2010. Gas chromatography-mass spectrometric determination of polybrominated diphenyl ethers in complex fatty matrices from aquaculture activities. Anal. Chim. Acta 664, 190-198. https://doi.org/10.1016/J.ACA.2010.02. 015.

Naile, J.E., Khim, J.S., Hong, S., Park, J., Kwon, B.-O., Ryu, J.S., Hwang, J.H., Jones, P.D. Giesy, J.P., 2013. Distributions and bioconcentration characteristics of perfluorinated compounds in environmental samples collected from the west coas of Korea. Chemosphere 90, 387-394. https://doi.org/10.1016/J.CHEMOSPHERE. 2012.07.033.

Núñez, M., Borrull, F., Pocurull, E., Fontanals, N., 2016. Pressurized liquid extraction followed by liquid chromatography with tandem mass spectrometry to determine pharmaceuticals in mussels. J. Sep. Sci. 39, 741-747. https://doi.org/10. 1002/jssc.201501046.

Pampanin, D.M., Le Goff, J., Skogland, K., Marcucci, C.R., Øysæd, K.B., Lorentzen, M., Jørgensen, K.B., Sydnes, M.O., 2016. Biological effects of polycyclic aromatic hydrocarbons (PAH) and their first metabolic products in in vivo exposed Atlantic cod (Gadus morhua). J. Toxicol. Environ. Health Part A Curr. Issues 79, 633-646. https://doi.org/10.1080/15287394.2016.1171993.

Pan, Y., Shi, Y., Wang, J., Jin, X., Cai, Y., 2011. Pilot investigation of perfluorinated compounds in river water, sediment, soil and fish in Tianjin, China. Bull. Environ. Contam. Toxicol. 87, 152-157. https://doi.org/10.1007/s00128-011-0313

Petrik, L., Green, L., Zackon, M., Sanusi, C.Y., Green, L., 2017. Desalination and Seawater Quality at Green Point , Cape Town : A Study on the Effects of Marine
Sewage Outfalls, vol. 113, pp. 1-10. https://doi.org/10.17159/sajs.2017/a0244.

Quinete, N., Wu, Q., Zhang, T., Yun, S.H., Moreira, I., Kannan, K., 2009. Specific profiles of perfluorinated compounds in surface and drinking waters and accumulation in mussels, fish, and dolphins from southeastern Brazil. Chemosphere 77, 863-869. https://doi.org/10.1016/j.chemosphere.2009.07.079.

Ramirez, A.J., Mottaleb, M.A., Brooks, B.W., Chambliss, C.K., 2007. Analysis of pharmaceuticals in fish using liquid chromatography-tandem mass spectrometry. Anal. Chem. 79, 3155-3163. https://doi.org/10.1021/ac062215i.

Richardson, B.J., Lam, P.K.S., Martin, M., 2005. Emerging chemicals of concern: pharmaceuticals and personal care products (PPCPs) in Asia, with particular reference to Southern China. Mar. Pollut. Bull. 50, 913-920. https://doi.org/10. 1016/j.marpolbul.2005.06.034.

Sapkota, A., Sapkota, A.R., Kucharski, M., Burke, J., McKenzie, S., Walker, P., Lawrence, R., 2008. Aquaculture practices and potential human health risks: current knowledge and future priorities. Environ. Int. 34, 1215-1226. https:/| doi.org/10.1016/J.ENVINT.2008.04.009.

Shi, Y., Pan, Y., Yang, R., Wang, Y., Cai, Y., 2010a. Occurrence of perfluorinated compounds in fish from Qinghai-Tibetan Plateau. Environ. Int. 36, 46-50. https://doi.org/10.1016/J.ENVINT.2009.09.005.

Shi, Y., Pan, Y., Yang, R., Wang, Y., Cai, Y., 2010b. Occurrence of perfluorinated compounds in fish from Qinghai-Tibetan Plateau. Environ. Int. 36, 46-50. https://doi.org/10.1016/J.ENVINT.2009.09.005.

Shi, Y., Pan, Y., Wang, J., Cai, Y., 2012. Distribution of perfluorinated compounds in water, sediment, biota and floating plants in Baiyangdian Lake, China. J. Environ. Monit. 14, 636-642. https://doi.org/10.1039/C1EM10772K.

Sinclair, E., Mayack, D.T., Roblee, K., Yamashita, N., Kannan, K., 2006. Occurrence of perfluoroalkyl surfactants in water, fish, and birds from New York State. Arch. Environ. Contam. Toxicol. 50, 398-410. https://doi.org/10.1007/s00244-0051188-z.

Stahl, L.L., Snyder, B.D., Olsen, A.R., Kincaid, T.M., Wathen, J.B., McCarty, H.B., 2014. Perfluorinated compounds in fish from U.S. urban rivers and the Great Lakes. Sci. Total Environ. 499, 185-195. https://doi.org/10.1016/J.SCITOTENV.2014.07. 126.

Sumpter, J.P. 1995. Feminized responses in fish to environmental estrogens. Toxicol Lett. 82-83, 737-742. https://doi.org/10.1016/0378-4274(95)03517-6.

Tanoue, R., Nomiyama, K., Nakamura, H., Hayashi, T., Kim, J.-W., Isobe, T., Shinohara, R., Tanabe, S., 2014. Simultaneous determination of polar pharmaceuticals and personal care products in biological organs and tissues. J. Chromatogr. A 1355, 193-205. https://doi.org/10.1016/J.CHROMA.2014.06.016.

Teixeira, M., Almeida, Â., Calisto, V., Esteves, V.I., Schneider, R.J., Wrona, F.J., Soares, A.M.V.M., Figueira, E., Freitas, R., 2017. Toxic effects of the antihistamine cetirizine in mussel Mytilus galloprovincialis. Water Res. 114, 316-326. https:// doi.org/10.1016/J.WATRES.2017.02.032.

Togunde, O.P., Oakes, K.D., Servos, M.R., Pawliszyn, J., 2012. Optimization of solid phase microextraction for non-lethal in vivo determination of selected pharmaceuticals in fish muscle using liquid chromatography-mass spectrometry. J. Chromatogr. A 1261, 99-106. https://doi.org/10.1016/j.chroma.2012.07.053.

US EPA, 2016. Technical Overview of Ecological Risk Assessment: Problem Formulation [WWW Document]. (last Updat. 31/12/2014). URL. https://www.epa.gov/ pesticide-science-and-assessing-pesticide-risks/technical-overview-ecologicalrisk-assessment-risk, accessed 9.13.18).

Vassiliadou, I., Costopoulou, D., Kalogeropoulos, N., Karavoltsos, S., Sakellari, A., Zafeiraki, E., Dassenakis, M., Leondiadis, L., 2015. Levels of perfluorinated compounds in raw and cooked Mediterranean finfish and shellfish. Chemosphere 127, 117-126. https://doi.org/10.1016/j.chemosphere.2014.12.081.

Waiser, M.J., Humphries, D., Tumber, V., Holm, J., 2011. Effluent-dominated streams. Part 2: presence and possible effects of pharmaceuticals and personal care products in Wascana Creek, Saskatchewan, Canada. Environ. Toxicol. Chem. 30, 508-519. https://doi.org/10.1002/etc.398.

Waliszewski, S.M., Aguirre, A.A., Infanzón, R.M., Siliceo, J., 2000. Carry-over of persistent organochlorine pesticides through placenta to fetus. Salud Publica Mex. 42, 384-390.

Wang, J., Gardinali, P.R., 2012. Analysis of selected pharmaceuticals in fish and the fresh water bodies directly affected by reclaimed water using liquid chromatography-tandem mass spectrometry. Anal. Bioanal. Chem. 404, 2711-2720. https://doi.org/10.1007/s00216-012-6139-8.

Wille, K., Kiebooms, J.A.L., Claessens, M., Rappé, K., Vanden Bussche, J., Noppe, H., Van Praet, N., De Wulf, E., Van Caeter, P., Janssen, C.R., De Brabander, H.F., Vanhaecke, L., 2011. Development of analytical strategies using U-HPLC-MS/MS and LC-ToF-MS for the quantification of micropollutants in marine organisms. Anal. Bioanal. Chem. 400, 1459-1472. https://doi.org/10.1007/s00216-0114878-6.

Xu, W., Yan, W., Li, X., Zou, Y., Chen, X., Huang, W., Miao, L., Zhang, R., Zhang, G. Zou, S., 2013. Antibiotics in riverine runoff of the Pearl river delta and Pearl river estuary, China: concentrations, mass loading and ecological risks. Environ. Pollut. 182, 402-407. https://doi.org/10.1016/J.ENVPOL.2013.08.004.

Yang, L., Zhu, L., Liu, Z., 2011. Occurrence and partition of perfluorinated compounds in water and sediment from Liao River and Taihu Lake, China. Chemosphere 83, 806-814. https://doi.org/10.1016/j.chemosphere.2011.02.075.

Yao, L., Lv, Y.-Z., Zhang, L.-J., Liu, W.-R., Zhao, J.-L., Liu, Y.-S., Zhang, Q.-Q., Ying, G.-G., 2018a. Determination of 24 personal care products in fish bile using hybrid solvent precipitation and dispersive solid phase extraction cleanup with ultrahigh performance liquid chromatography-tandem mass spectrometry and gas chromatography-mass spectrometry. J. Chromatogr. A 1551, 29-40. https:// doi.org/10.1016/J.CHROMA.2018.04.003. 
Yao, L., Zhao, J.-L., Liu, Y.-S., Zhang, Q.-Q., Jiang, Y.-X., Liu, S., Liu, W.-R., Yang, Y.-Y., Ying, G.-G., 2018b. Personal care products in wild fish in two main Chinese rivers: bioaccumulation potential and human health risks. Sci. Total Environ. 621, 1093-1102. https://doi.org/10.1016/J.SCITOTENV.2017.10.117.

Ye, X., Strynar, M.J., Nakayama, S.F., Varns, J., Helfant, L., Lazorchak, J. Lindstrom, A.B., 2008. Perfluorinated compounds in whole fish homogenates from the Ohio, Missouri, and Upper Mississippi Rivers, USA. Environ. Pollut. 156, 1227-1232. https://doi.org/10.1016/J.ENVPOL.2008.03.014.

$\mathrm{Yu}, \mathrm{Y}, \mathrm{Wu}, \mathrm{L} ., 2014$. Determination and occurrence of endocrine disrupting compounds, pharmaceuticals and personal care products in fish (Morone saxatilis). Front. Environ. Sci. Eng. 9, 475-481. https://doi.org/10.1007/s11783-014-0640-

Zabaleta, I., Bizkarguenaga, E., Iparragirre, A., Navarro, P., Prieto, A., Fernández, L.Á., Zuloaga, O., 2014. Focused ultrasound solid-liquid extraction for the determination of perfluorinated compounds in fish, vegetables and amended soil.
J. Chromatogr. A 1331, 27-37. https://doi.org/10.1016/J.CHROMA.2014.01.025. Zhang, R., Tang, J., Li, J., Cheng, Z., Chaemfa, C., Liu, D., Zheng, Q., Song, M., Luo, C. Zhang, G., 2013. Occurrence and risks of antibiotics in the coastal aquatic environment of the Yellow Sea, North China. Sci. Total Environ. 450-451 197-204. https://doi.org/10.1016/j.scitotenv.2013.02.024.

Zhao, Y.G., Wan, H.T., Law, A.Y.S., Wei, X., Huang, Y.Q., Giesy, J.P., Wong, M.H. Wong, C.K.C., 2011. Risk assessment for human consumption of perfluorinated compound-contaminated freshwater and marine fish from Hong Kong and Xiamen. Chemosphere 85, 277-283. https://doi.org/10.1016/J.CHEMOSPHERE. 2011.06.002.

Zhao, J.L., Liu, Y.S., Liu, W.R., Jiang, Y.X., Su, H.C., Zhang, Q.Q., Chen, X.W., Yang, Y.Y., Chen, J., Liu, S.S., Pan, C.G., Huang, G.Y., Ying, G.G., 2015. Tissue-specific bioaccumulation of human and veterinary antibiotics in bile, plasma, liver and muscle tissues of wild fish from a highly urbanized region. Environ. Pollut. 198, 15-24. https://doi.org/10.1016/j.envpol.2014.12.026. 